\title{
Dijital Aktivizm Platformu Change.Org'da Başarıya Ulaşmış Kampanyalara Yönelik Bir Çalışma
}

\section{A Study On The Campaigns Succeeded On Digital Activism Platform Change.org}

\author{
Prof. Dr. Ece Karadoğan Doruk \\ İstanbul Üniversitesi Illetişim Fakültesi, \\ Halkla İlişkiler ve Tanıtım Bölümü \\ Ayda Akbıçak \\ Türk-Alman Üniversitesi, \\ Basin ve Halkla Illişkiler Koordinatörlüğ̈̈
}

\begin{abstract}
Özet: Dijital teknolojilerin küresel anlamda yaşamlarımıza egemen olması, tutum ve davranışlarımızı, iletişim biçimlerimizi, sosyal yaşantılarımızı derinden etkilemiş ve değiştirmiştir. Yaşamın içinde yer alan pek çok uygulama dijital ortamlarda yer alan sosyal platformlara taşınmıştır. Toplumu yönetenlerin bazı karar ve uygulamalarından hoşnut olmayan bireylerin, baskı gruplarının, lobilerin de yeni buluşma noktalarından biri artık dijital aktivist platformlardır. Bu çalışmada, en çok tercih edilen dijital aktivist platformlardan biri olan Change.org incelenmiş, sitede ilan edilen başarıya ulaşmış projelerin ilk 30 adedi çeşitli başlıklar altında değerlendirilmiştir. Değerlendirmede başlıklar arasında korelasyon aranmış, projeler arasındaki ilişkisellikler sorgulanmıştır. Araştırma sonuçlarını anlamlandıma sürecinde, sağlık ve çevre konulu kampanyaların başarıya ulaşma olasılığının diğerlerine göre daha yüksek olduğu, sağlık konulu projelerin daha çok imza topladığı, başarıya ulaşmış projelerin tamamının sosyal medyada yer alırken 18 'inin geleneksel medyada da yer alması nedeniyle geleneksel ve sosyal medyaların birbirini desteklediği, sosyal medyadaki sayısal çoğunluğun geleneksel medya üzerinde baskı yaratabildiği sonuçlarına varılmıştır.
\end{abstract}

\section{Anahtar Kelimeler: Dijital Aktivizm, Change.org, Sosyal Medya, Lobicilik, Baskı Grupları}

Extended Abstract: New media technologies and social networks builds networks of meanings among the different citizen groups of civil society in terms of civil society being organized and making their voices heard as something vitally important in democratization. As we witnessed in many life practices with digital communication technologies reigning over our lives, activism works started to use digital platforms, too. Online activism is defined as usage of internet communication technologies for various forms of activism (Sert, 2012:129). And digital activism according to Uçkan is a general name given to the internet usage of different activism forms (2012). With activism becoming digitalized, individuals thinking that they have performed their social responsibilities with one click are criticized by some. As a response to these criticisms, Change.org campaign expert Paktin argues that digital activism does not change the world with two clicks but it strengthens the idea that the world is changeable with each click (2013). 
In this study, Change.org, one of the most preferred digital activist platforms with 125 million users globally is analyzed. The analysis covers the first 30 projects in the list of successful projects announced between the dates of November $2^{\text {nd }}$ - December $2^{\text {nd }} 2015$ on Change.org. The sample is limited to Change.org, that has the most widespread working area in a global level. The aforementioned 30 projects are evaluated under the titles of subject, success time, signature count, campaign initiator, campaign collocutor, whether the campaign was on traditional and social media, whether the campaign subject was discussed at the Grand National Assembly of Turkey. The evaluation includes that whether there is a correlation between these sections or not and aims to form a success index. Change.org is examined deeply using the method of descriptive analysis and the numerical data received is tabulated using the content analyzing technique. The purpose of the study is to make it easier for us to understand the effects of digital communication technologies on forms of social organizing. The importance of the study is based on showing that digital communication technologies transform our lives and how alternative views which have a hard time to be voiced through traditional media can get organized thanks to these technologies, as well as examining the common traits or differences of the successful projects.

The activist platform that is the subject of the study is being examined in context of studies of Harold Innis (2006), who voices that communication technology is a representative of political and economic process, that 'information moguls' determined by technology direct the split of political power between society's groups (Irge, 2012: 67) and that deprived groups in the society lead the technological advances to gain power.

In order according to the number of projects, subject titles are as 6 about health, 5 about environment, 4 about animal rights, 4 about education, 3 about women's rights, 2 about entertainment and 6 projects as others taking place under different subject titles. Throughout the tables, it is seen that the projects about health succeeded the most and the projects with a higher count of signatures have appeared in both traditional and social media as a news event. The projects with a higher signature count were subject to the discussions in the Grand National Assembly of Turkey. The reason of this can be thought as both the signature count being high and various ministries being chosen as addressee. Also, it is seen that the projects about health could collect many more signatures. On social activism sites such as Change.org, besides the signature count being important as an oppression element, the addressee of the project and the project being published in all media choices are also effective elements for success.

All projects about environment appeared in both traditional and social media, and were started by individuals. None of the four projects about animal rights were discussed at the Assembly. Among the four projects about education, the project with the most signature count is addressed to YÖK, concerning a great number of students. It is seen that the succeeded campaigns about Women's Rights and Human Rights did so in a very short time. It is remarkable that all three projects about women's rights are about television programs, and were initiated by women. Especially the private firms produced a solution in a short time for the projects initiated on Change.org. In our times, it is impossible for companies that don't heed the social media to succeed.

Manufacturers and distributers of digital technologies that allow expansionist policies, form information moguls and make the countries that they sell these technologies to, dependent on them. Sovereign powers who control information moguls, also have the power to inspect, and stop if necessary, the institutions that perform research and development besides themselves. Communication technologies may not be the only identifiers of social transforming as Innis has defended but it's a fact that they have an important role in this transformation. 
Alternative opinions that could not make their voices heard via traditional media, can get together, form groups, organize quickly and take action thanks to interactive internet systems. Activities of organizations like Change.org must be evaluated in this context. Another advantage of the campaigns is to make important subjects that get overlooked or fall from our agendas because of the daily bombardment of information, stay in the agenda. Sites that activist actions are carried out on, are significant platforms in terms of helping people about the problems they have, giving them a chance to show their sensitivity about specific subjects, create alternative solutions, make their voices heard by the authorities and get the support of other people that think and feel just like themselves. In terms of catching the attention of politic authority that has the legislative power, about certain subjects, and conducing toward getting desirable results, sites as Change.org can be an important lobbying tool. It must be expected that we would face more of different formations in the future due to new media technologies that are still thought to be in the infancy period.

\section{Keywords: Digital Activism, Change.org, Social Media, Lobbying, Pressure Groups}

\section{GíRiş}

Sosyologlar, toplumsal hayat tarihini üretim araçlarına göre sınıflar. Buna göre kültürün başlangıcı pişirme eylemi olarak kabul edilir. Toplumsal hayatın ilk evresinde insan, ellerini kullanarak toplayıcılık yapmış, ikinci evrede ilkel araçların üretimiyle avcılık deneyimi başlamıştır. Sonraki evrede toprağı ekip biçmeyi sağlayan çeşitli araçlarla tarım toplumuna geçilmesi gerçek anlamda yerleşikliği getirmiştir. Bunu 18. ve 19. yüzyıllarda Avrupa'daki buluşların etkisiyle buhar gücüyle çalışan makinelerin üretilmesi izlemiştir. Böylelikle, sanayi toplumu gündeme gelmiş, seri üretim başlamış, tarımsal üretimin tarım toplumuna göre oransal olarak azaldığı toplumsal bir yapıya geçilmiştir. Bu toplum yapısında asıl olan insan gücü değil, makinenin gücüdür. İş bölümü artmış, verimlilik çoğalmış, kentleşme başlamış, insanoğlu kültürel bir dönüşüm yaşamıştır. İçinde bulunduğumuz yeniçağla birlikte ise bilgi toplumu olgusu gündeme gelmiştir. Artık insanoğlunun sermayesi ve ekonominin başlıca hammaddesi bilgidir. Zihinsel sermayenin belli bir yere sınırlanmayan yapısı, bütün yönetim ve toplum ilişkilerini değiştirmiştir.

Bazı iletişim kuramcıları ise insanlık tarihini üretim araçlarına göre değil, iletişim biçimlerine göre sınıflandırmışlardır. Örneğin McLuhan insanlık tarihini dört ana başlık altında toplar: Sözlü kültürün egemen olduğu Kabile Çağı, fonetik alfabenin bulunuşu ile başlayan Edebiyat Çağı, basım teknolojisinin hayata geçişiyle gelişen Basım Çağı ve içinde bulunduğumuz Elektronik Çağ (Aydoğan, 2013: 38). Sözü geçen çağların en belirgin özelliğini, bilgilerin giderek daha hızlı ve ucuz dağıtılması oluşturmaktadır (Kınay, 2014). Teknolojinin toplumların dönüşümünde belirleyici olduğunu savunan kuramcılara göre, iletişim araçlarındaki/teknolojilerindeki değişimler; ekonomik, siyasal, sosyal ve kültürel dönüşümleri birlikte getirmektedir. Bu dönüşümlerin temel lokomotiflerinden birinin internet bazlı iletişim ve daha özelinde sosyal medya olduğu pek çok çalışmada vurgulanmaktadır.

Sosyal medya zaman ve mekân sınırlaması olmayan, internet tabanlı bir iletişim sistemidir (Vural, 2010, Erişim Tarihi: 16.12.2017). İnsanların hikayelerini ve tecrübelerini videolar, görseller ve diğer çeşitli teknolojik unsurlar vasıtasıyla paylaştığı sosyal, sosyalin ötesinde sanal paylaşma ve tartışma ortamıdır. İnsanlar sosyal medya vasıtasıyla kurumlarını, ürünlerini, çalışmalarını tanıtma, yeni arkadaşlık ilişkileri kurma, birlikteliklergruplar oluşturarak düşüncelerini toplu olarak duyurma fırsatı elde etmektedirler.

Bu çalışmada yeni medya teknolojilerinin toplumsal örgütlenmenin bir boyutu olan aktivizmi dijital boyuta taşıması ve dijital aktivizm pratiklerinin gerçek hayatta nasıl karşılık bulduğu irdelenmiştir. Çalışmanın araştırma kısmında ise tüm dünya genelinde 125 milyon kullanıcı sayısı ile en çok tercih edilen dijital aktivist 
platformlardan biri olan Change.org incelenmiştir. İnceleme 2 Kasım - 2 Aralık 2015 tarihleri arasında Change.org'da ilan edilen başarıya ulaşmış projeler listesinin ilk 30 adedini kapsamaktadır. Çalışmaya konu olan 30 proje; konusu, başarı süresi, imza adedi, kampanyayı başlatan, kampanyanın muhatabı, kampanyanın geleneksel ve sosyal medyada yer alıp almadığı, kampanya konusunun TBMM'de görüşülüp görüşülmediği başlıkları altında değerlendirilmiştir. Değerlendirme tüm bu başlıklar arasında bir korelasyon olup olmadığını içermektedir. Çalışma, hem dijital iletişim teknolojilerinin yaşam biçimlerimizi çok hızlı biçimde dönüştürmekte olduğunu hem de geleneksel medya yoluyla seslerini duyurmakta zorlanan alternatif görüşlerin bu teknolojiler sayesinde nasıl örgütlenebildiklerini göstermesi açısından önem arz etmektedir. Çalışmanın ikinci bölümünde kuramsal ve kavramsal çerçeveler çizilmekte, üçüncü bölümünde saha çalışması ele alınmaktadır.

\section{YENI MEDYA TEKNOLOJILERI VE AKTIVIZM OLGUSU}

\subsection{Yeni Medya Teknolojileri ve Sosyal Medya}

Yeni medya, "kitle izleyicisini bireysel kullanıcı olarak da kapsayabilen, kullanıcıların içeriğe veya uygulamalara farklı zaman dilimlerinde ve etkileşim içinde erişebildikleri sistemler" olarak tanımlanmaktadır (Geray, 2003: 20). Yeni medya ya da sosyal medya internetin kullanıma girmesinin ardından gelişmeye başlamıştır. Yeni medya dendiğinde bilgisayarların işlem gücü olmadan oluşturulamayacak veya kullanılamayacak ortamları anlamaktayız. Bu ortamlar genellikle dijital olup kullanıcısına veya hedef kitlesine etkileşim olanağı sağlamaktadır. Önceleri elektronik posta (e-posta) iletişimi düzeyinde başlayan süreç son birkaç yıl içerisinde hızla ilerleyerek Messenger, GTalk, Facebook, Myspace, Twitter gibi sanal iletişim ortamlarıyla yaşamımıza girmiştir (Güngör, 2011: 312).

Internet kullanıcılarının birbirleriyle tanışması, irtibata geçmesi, içerik paylaşımında bulunması, tartışma ortamı oluşturması ve ortak ilgi alanlarındaki kişilerin bir araya gelebileceği gruplar oluşturulması amacıyla kurulan internet siteleri sosyal ağlar olarak tanımlanmaktadır. Ülkemizde oldukça popüler olan Facebook buna bir örnektir.

Bireylerin internette birbirleriyle yaptığı diyaloglar ve paylaşımlar sosyal medyayı oluşturmaktadır. Sosyal ağlar, bloglar, mikro bloglar, anlık mesajlaşma programları, sohbet siteleri, forumlar gibi insanların birbiriyle içerik ve bilgi paylaşmasını sağlayan internet siteleri ve uygulamalar sayesinde internet kullanıcıları aradıkları ve ilgilendikleri içeriklere ulaşma fırsatına erişmektedir.

Web 2.0'ın kullanılmaya başlanmasıyla birlikte kullanıcı tabanlı sosyal medya, kitleleri ve insanları bir araya getirmekte ve aralarında senkron (eş zamanlı: Messenger) ve asenkron (eş zamanlı olmayan: e-mail) olarak etkileşim sağlamaktadır. Bununla birlikte kullanıcılar sosyal ağlar sayesinde paylaşılan bilginin içeriğine katkıda bulunarak etkileşimi arttırmaktadır. Insanlara duygu, düşünce ve eserlerini paylaşma imkanı veren sosyal ağlar (Facebook, Twitter vb.) kişiye toplumsal konular üzerinden yorum yapabilme ve tepkilerini dile getirme olanağı da sağlamaktadır. Bu yeni sanal ortamlarla bir yandan yeni bir iletişim biçimi gelişirken, diğer yandan da insanlar için sanal da olsa yeni sosyal alanlar açılmıştır (Güngör, 2011: 312). Bu teknolojinin belki de en önemli özelliği, geleneksel medyanın alıcı konumundaki bireylerine, bloglar, web siteleri, sosyal paylaşım ağları üzerinden kendi mesaj içeriklerini oluşturup paylaşarak kendilerini ifade etme fırsatı sunmasıdır. Gündelik yaşamda kişilerin katıldıkları protesto gibi sosyal eylemlerin benzerleri artık sanal ortamlarda yaşanır olmaktadır.

Chomsky; yeni medya teknolojilerinin büyük medya tekellerinin ve devletin kontrolü dışında yurttaş kontrolündeki medya olduğunu ileri sürmekte, Dargon ise, yeni medya teknolojilerini üçüncü medya olarak tanımlayarak, politik partilerle organik bir ilişkisi olmayan ancak toplumsal hareketlerin eti ve kemiğini oluşturduğunu söylemektedir (Türk, 2013: 56). Demokratikleşmede hayati önem taşıyan sivil toplumun 
örgütlenmesi ve sesini duyurması açısından yeni medya teknolojileri ve sosyal ağlar, sivil toplumun gözeneklerine girerek farklı yurttaş toplulukları arasında anlam ağları inşa etmektedir. Keane'e göre, modern yaşamın atomlaştırıcı etkisine karşı toplumun daha güçüz kesimleri arasında sarsılanların dayanışmasını sağlamakta, merkeziliğine son verilmiş iletişim ağları sayesinde birçok yurttaş çeşitli örgütler aracılığıyla sivil toplum içinde yer alabilmektedir (Türk, 2013: 57).

\subsection{Bireyin Kendini İfade Etme Şekli Olarak: Protesto ve Baskı Grupları, Lobicilik, Aktivizm Kavramları}

Türk Dil Kurumunun açıklamasına göre protesto; bir davranışı, bir düşünceyi, bir uygulamayı haksız, yersiz, gereksiz bularak karşı çıkma, kabul etmeme durumudur. Bir diğer açıklamaya göre de herhangi bir davranışın haksız, yersiz, gereksiz görülerek onaylanmadığını bildiren resmî açıklamadır. "Protesto etmek" kavramı da itiraz etmek, reddetmek anlamında kullanılmaktadır (http://tdk.org.tr).

Protesto, göreceli olarak bir olaya ve duruma karşı aksi yönde tepki göstermektir. Genellikle bu tepki gösterme biçimi, muhalif görüşü sözle ifade etme yanında o görüşü toplumsallaştırma ve bir grupla birlikte ifade etme karakteri de taşır. Bundaki amaç kamuoyu nezdinde sesini daha çok duyurabilmek ve yönetime karşı daha etkili bir duruş sergileyebilmektir. Bu, doğrudan ifade ve etkilemenin, yani aktivizmin bir yoludur (Karpınar, 2016, Erişim Tarihi: 16.12.2017).

Tarihin her döneminde egemen güçlere karşılık muhalif gruplar var olmuştur. Toplumda iktidarı ellerinde bulunduran güçlerle farklı görüşlere sahip olan muhalif gruplar; lobicilik, aktivizm, eylemcilik gibi sosyal hareketlerle kendilerine tanınan alan içinde bir araya gelerek seslerini duyurmaya çalışmışlardır. Gerçek hayatta protesto şekilleri; sivil itaatsizlik, grev, açlık grevi, yürüyüş, miting, toplu imza, fiziksel eylem (ışık kapama, yaka kartı kullanma gibi), iş bırakma vb. sıralanabilir. Sanal ortamın, gerçek yaşamın bir yansıması olduğundan söz etmiştik. Bu bağlamda sanal protesto ise, insanların gerçek hayatta değil, toplumsal olaylar karşısındaki tepkilerini sosyal ağlar tarafından oluşturulan sosyal medya ortamında göstermeleridir. Sanal protesto türleri; kişisel hesaplarını dondurma, profil fotoğrafı değiştirme, konu ile ilgili gruplar oluşturup kullanıcıları davet etme, sosyal aktivizm sitelerinde imza kampanyaları başlatma ve bunların yanı sıra kurulmuş gruplara katılma, konu ile ilgili fotoğraf veya video paylaşma, sayfa hacklenmesi vb.dir.

Giddens sosyal hareketleri; "Yerleşik alanın dışındaki toplu eylemler yoluyla, ortak bir çıkarı korumak ya da ortak bir hedefe erişmeyi sağlamak için girişilen toplu bir çaba" olarak tanımlar ve sosyal hareketlerin ortak bir amaç etrafında bir araya gelme özelliğine, içerisinde muhalif bakış açılarını içermesine, dinamik ve kolektif bir davranış olmasına dikkat çeker (Meriç, 2012). Bir araya gelmiş muhalif gruplar çeşitli biçimlerde organize olabilirler ve çalışmalarını farklı zeminlerde, değişik yollarla yürütebilirler. Turan'a göre, en genel tanımıyla baskı grubu; "üyelerinin ortak çıkarlara sahip bulunduklarını algılayan ve iktidara geçmeyi amaçlamadan siyasal sistemi etkilemeye çalışan bir topluluktur (Arsava ve Çerçi 2006: 5). Lobicilik ise, Kazancı'ya göre, ikna ve inandırma teknikleri uygulayarak, karar verme mekanizmaları üzerinde baskı oluşturma ve politik kararları bir grubun veya bir ülkenin lehine-aleyhine çevirebilme becerisidir (Arsava ve Çerçi 2006: 1112). Lobicilik doğrudan yapılabildiği gibi kamuoyunu veya kitleleri etkileyerek dolaylı yoldan da yapılabilmektedir. Dolaylı lobicilik tekniği ile kitlelerin ve medyanın etkilenerek harekete geçirilmesinin sağlanması, kamuoyu oluşturularak karar vericiler üzerinde etki yaratmak amaçlanmaktadır. Bu amaçlar doğrultusunda lobiciler kamuoyu kampanyaları, toplantı ve konferanslar düzenlemek, hedeflenen kişilere ve medyaya mektup, telgraf, elektronik posta, faks, dilekçe göndermek gibi yöntemler kullanmaktadırlar. Bu şekilde kanun yapıcılar ve karar mekanizmasında etkin hedef kişiler üzerinde sadece doğrudan lobicilik yoluyla elde edilmesi zor olan bir baskı oluşturabilmektedirler (Arsava ve Çerçi 2006). Dinçer'e göre, baskı grupları ve lobiler arasındaki fark; baskı gruplarının belirli çıkarlar çevresinde, ortak amaca yönelik olarak kurulmaları ve iktidarla ilişkilerinin çalışmalarının sadece bir kesitini oluşturması, lobilerin ise devleti idare edenler üzerinde 
türlü yollardan etkinlik sağlayarak, karar aldırma amacıyla faaliyet gösteren gruplar ya da kuruluşlar olmalarıdır (Aslan, 2015).

Muhalif grupların en temel halini eylemciler ya da diğer adıyla aktivistler olarak tanımlanan gruplar oluşturmaktadır. Grunig ve diğerleri bir eylem grubunu, “eğitim, uzlaşma, ikna, baskı teknikleri ya da güç kullanımı gibi eylemler aracılığıyla başka bir kamuyu ya da kamuları etkilemek üzere örgütlenmiş iki ya da çok insanın oluşturduğu bir topluluk," olarak tanımlarlar (2005: 528).

Genel anlamda protesto ile eş anlamlı kullanılan aktivizm, toplumsal değişme ya da politik değişiklik meydana getirmek için kasıtlı bir biçimde yapılan eylem olarak tanımlanabilir. Bu eylem çelişmeli tartışmalarda taraflardan birini desteklemek anlamında kullanılmaktadır. Aktivizm bir gazeteye ya da politikacıya bir mektup yazmaktan, politik kampanyadan, ekonomik aktivizmden (tercih edilen şirketleri desteklemek veya boykot etmek gibi), toplantılardan, blog yapmaktan ve sokak yürüyüşlerinden grevlere ve hatta gerilla taktiklerine kadar geniş bir yelpazede değerlendirilebilir. Bayat'a göre, aktivizm, insanların yaşamlarında değişim yaratmayı amaçlayan her türlü bireysel ya da toplumsal, kamusal ya da gayri resmi beşeri etkinliği ifade etmektedir (Sert, 2012: 128). Daha geniş bir tanımlamayla; bireylerin, kurumların ya da hükümetlerin sergilediği yanlış, hatalı ya da zararlı sonuçları olduğuna inanılan davranışlara karşı gerçekleştirilen eylemlere aktivizm, bu eylemlerde bulunan kişilere aktivist denilmektedir (Sert, 2012: 128).

\subsection{Dijital Aktivizm Olgusu}

Dijital iletişim teknolojilerinin yaşamlarımıza egemen olması ile birçok yaşam pratiğinde tanık olduğumuz gibi, aktivizm çalışmaları da dijital platformları kullanmaya başlamıştır. Online aktivizm ya da siber-aktivizm genellikle, aktivizmin çeşitli formları için internet iletişimi teknolojilerinin kullanılması olarak tanımlanmaktadır (Sert, 2012:129). Uçkan'a göre ise dijital aktivizm, farklı aktivizm türlerinin internet kullanımına verilen genel bir isimdir. Terimin 'internet aktivizmi', 'e-aktivizm', 'siber aktivizm' gibi kullanımları da vardır. Aktivizm çerçevesinde internet kullanımında; bir amacın savunusu, bu amacı gerçekleştirmek için örgütlenme, amaca yönelik mesajları kitlelere iletme, lobi faaliyetleri gerçekleştirme, boykot, site karartma gibi internet üzerinde eylem gerçekleştirme, amaca yönelik kaynak toplayıp fon oluşturma, hükümet veya şirketleri izleyerek faaliyetlerini raporlama gibi aktivist faaliyetlerin, geniş kitlelere gerçek zamanlı bilgi ulaştırabilecek imkânları tanıyan alanlarda (sosyal medya, blog, vlog, podcast, video, fotoğraf paylaşım siteleri vb.) gerçekleştirilmesi yer alır (2012).

Tarihsel gelişim açısından dijital aktivizm incelendiğinde; başlangıcının, henüz internet geliştirilmeden, Amerikan askeri yapılarıyla kimi üniversitelerin haberleşme için kullandıkları ağlarda bulunduğunu ifade etmek olasıdır. Bu ağlar üzerinde yükseköğrenim gençliğiyle ağı kuran bilim adamları arasında mail grupları kurulmuş, bu gruplarda siyaset tartışılmış, çeşitli örgütlenmeler kurgulanmıştır. Uçkan'a göre, 'kripto anarşizm', 'siberpunk' ve 'hacktivizm' gibi dijital aktivizmle bağdaştırılabilecek ilk dijital aktivist formlar bu ortamda oluşmuştur (2012).

1970'li yılların sonundan 1990'lara kadar internet geliştirilmiş, haberleşme odaklı çeşitli gruplaşmalar oluşmuş, aktivistler teknolojideki her yeni gelişmeyi kendilerine uyarlayarak aktivizmi çeşitli formlarda kullanmışlardır. Bunun nedenlerinden biri, teknolojideki gelişmelerde payı bulunanlardan bazılarının, aynı zamanda aktivist kimliğine sahip oluşudur. 1990'lı yıllardan sonra hız kazanan dijital teknolojideki gelişmelerle ve interaktif iletişime izin veren web 2.0 teknolojisi, Wap, 3 G gibi yeniliklerle aktivizm çok daha geniş bir eylem repertuarı kazanmıştır. Türkçeye 'miskin eylemcilik' olarak çevrilebilen slacktivism, bu kavramın bir adım ötesinde eylem alanına sahip olan 'clicktivism' ve web sitesi hacklemek, bir hedef seçerek virüs göndermek, bir 
kurumu aşırı mail bombardımanına tutmak biçiminde çeşitli eylemleri içeren 'hacktivism' gibi dijital aktivizm formları gündemimize girmiştir (Turhan, D.G., 2017, Erişim Tarihi: 16.12.2017) .

Aktivizmin dijitalleşmesiyle bireylerin oturdukları yerden bir tıkla sosyal sorumluluklarını yerine getirdiklerini düşünmeleri bazı kişilerce eleştirilmektedir. Bu eleştirilere karşılık Change.org kampanya uzmanı Paktin, dijital aktivizmin iki tıkla dünyayı değiştirmediğini, her bir tıkla dünyanın değiştirilebilir olduğu fikrini biraz daha güçlendirdiğini savunur. Ona göre dijital aktivizm bir mücadele yöntemi değildir. Dijital aktivizm mücadele edilecek insanları bir düşünce, bir inanç çevresinde toplama ve onları harekete geçirme yöntemidir. Dijital aktivizm tek başına hiçbir şeyi değiştirmez ancak değiştirecek olan kişileri bir araya getirir. Gerisini bu kişilerin oluşturduğu ‘kolektif düşünce' yapar (2013). Buna karşılık Avar'a göre, Change.org ve benzeri kuruluşlar bir anlamda şantaj kurumu gibi çalışmakta, kime hizmet veriyorlarsa, rakip tarafın politikacılarını, şirketlerini, lobilerini kampanyalar vasıtasıyla zor duruma düşürmekte, bunların yanı sıra 200'e yakın ülkedeki milyonlarca kişinin bilgilerini ve eğilimlerini pazara sunmaktadırlar. Yazar bu vasıtayla oturduğu yerden sosyal düşünen kitlelere tatmin duygusu sunulduğunu da ekler ve uyarır: "Sözün özü, oturduğumuz yerde kalmamız için önümüze sürülen her numaraya dalmayalım...! (2015). 20 Kasım 2013 tarihli Meydan gazetesindeki bir yoruma göre de, Change.org adındaki .org uzantısı, multi milyon dolar geliri olan bir kuruluşu gizlemek için kullanılırken, kampanyaları imzalayanların mail adresleri veri ticareti olarak değerlendirilmekte, e-posta adresleri birim fiyatı 1.75 Dolara kadar çıkabilen fiyatlar üzerinden başka kuruluşlara satılmaktadır (2013).

\subsection{Bir Dijital Aktivizm Platformu: Change.org}

Change.org (www.change.org), 2007 yılının Şubat ayında kurulmuştur. Merkez ofisi, ABD’nin Delaware eyaletinde bulunmaktadır. Şirketin kurucusu ve şu anki CEO’su Ben Rattray, operasyonlardan sorumlu başkanı ise kuruluşa 2013 yılında katılan Jennifer Dulski'dir. Sitenin misyonu, “insanları her yerde görmek istedikleri değişimi yaratmaları için güçlendirmektir." Bu misyon ışığında site, bireylere ücretsiz imza kampanyaları düzenlemeleri için destek vermektedir. Ancak kampanya sahipleri veya destekçileri, belli bir ödeme karşılı̆̆ında dilekçelerinin, diğerleri içinden sıyrılarak, açık kampanyalar listesinin üst sıralarında yer almasını sağlama fırsatına sahiptir. Sıralamada ilk sıralara yükselen kampanyaların imza alma ve başarıya ulaşma şansı artmakta, bu tarz kampanyalar 'sponsorlu kampanya' olarak tanımlanmaktadır. Site ücret karşılığında özel kuruluşlara da kampanyaları için ev sahipliği yapmaktadır. Ayrıca aralarında Amnesty International (Uluslar arası Af Örgütü) ve Humane Society gibi kuruluşların da yer aldığı, kar amaçlı olmayan veya siyasi kampanyalar, Change.org'a imza kampanyalarına ev sahipliği yaptığı için ücret ödemektedirler.

Sitede en popüler kampanya başlıklarının; ekonomi, adli yargı, insan hakları, eğitim, çevrenin korunması, hayvan hakları, sağlık ve sürdürülebilir gıda olduğu görülmektedir (Wikipedia.org, 2015). Rattray'in 2007 yılında kendi evinde kurduğu sitenin ilk kuruluş amacı sosyal aktivizm amaçlı bir sosyal ağken sonrasında 'sebep tabanlı' (cause based) blog platformuna çevrilmiş, 2011 yılında ise bildiğimiz haline, bir dilekçe platformuna dönüşmüştür. Rattray'e göre sitenin kuruluş amacı, bireyler ve büyük organizasyonlar arasındaki güç dengesini değiştirmektir. Personele gönderdiği bir e-postada: “Insanlar başkalarıyla daha hızlı ve etkin bir biçimde organize olma kapasitesine sahip olduklarında, insanlık tarihinde görülmemiş şekilde gücün kilidini açarlar," demektedir.

Change.org sitesinden 16.11.2017 tarihinde alınan bilgilere göre, site 196 ülkede faal durumdadır, erişim tarihindeki kullanıc sayısı 209.336.497'dir ve o ana kadar başarıya ulaşmış kampanya sayısı olarak 24.000 proje verilmektedir. Sitede yapılan iş, 'toplumsal fayda için bir iş modeli' olarak betimlenmekte, şirket kendini 'sosyal şirket' olarak tanımlamaktadır. Ayrıca sitede elde edilen gelirin tamamının kullanıcılara sunulan hizmetler için yeniden yatırım olarak kullanıldığı belirtilmekte, kar elde etmek yerine görev odaklı çalışmaları nedeniyle isimlerinin sonunda '.com' değil, '.org' uzantısı olduğunu açıklamaktadırlar. Şirket, yeni bir şirket sınıfı 
olan 'Sertifikalı Sosyal Şirkettir' (B Corporation). Bu sertifikaya sahip olmak için bağımsız bir grup tarafından belirlenen çok yüksek sosyal ve çevresel başarı standartları gerektiği belirtilmiştir. Sitede ücretsiz küresel kampanya platformunun; YouTube'daki sponsorlu videolardan, Google'daki sponsorlu linklerden, Twitter'daki sponsorlu tweetlerden ve kurumlardan sponsorlu imza kampanyaları formatında reklam alarak finanse edildiği açıklanmaktadır.

Change.org, 2017 yılının Ocak ayı itibariyle kullanıcılarına gelir modelini değiştirdiğini, bundan böyle kampanyaların sadece kullanıcıların maddi katkılarıyla oluşturulacağını duyurmuş ve kullanıcılarını platformun güçlü, bağımsız ve açık bir platform olarak tutulabilmesi için 'aylık destek' adı altında bağışta bulunmaya davet etmiştir.

Sitede ayrıca 'Reklam Kuralları', 'Topluluk ilkeleri', bireysel kullanıcılar için 'Yapabileceklerin' ve 'Yapılamayacaklar' başlıkları altında bilgiler bulunmaktadır. 'Yapabileceklerin' başlığı altında bireysel olarak bir imza kampanyası başlatmak ve bu kampanyayı başarıya ulaştırmak için yöntemler anlatılmakta, 'Yapılamayacaklar' bölümünde ise bireylerden kampanyalarını oluştururken nefret ve şiddet içeren söylemlerden uzak durmaları, gerçek kimliklerini kullanmaları, başkalarının özel hayatlarını ihlal etmemeleri istenmekte, ayrıca sataşmalardan ve gereksiz yere çarpıcı görsel kullanımından kaçınmaları önerilmektedir. Change.org kullanıldığı her ülkede o ülkenin anadili üzerinden kampanyalara ev sahipliği yapmakta, siteye hangi ülkeden giriş yapılıyorsa o ülkenin dilinde ve o ülkede açılmış projelerle karşılaşılmaktadır. Change.org Türkiye ofisinin kuruluş tarihi 2012 yılının Eylül ayıdır. Dr. Uygar Özesmi, Change.org'un Doğu Avrupa ve Batı Asya Direktörüdür. Erhan Çokkeçeci Kampanya Direktörü, Serdar Paktin ise Kampanya Uzmanı olarak görev yapmaktadırlar. Change.org sitesinden araştırma kapsamına aldığımız projeler incelendiğinde önümüze gelen konu başlıkları; adli yargı, güvenlik, hayvan hakları, spor, sağlık, çevre, eğitim, gıda, kadın hakları ve engelli hakları olmuştur.

Change.org incelendiği üzere imza toplamaya yönelik bir dilekçe platformudur. Dilekçe sahipleri genelde bireyler ve dernekler gibi sosyal kuruluşlardır. Kampanya başlıkları; devletten ilaç talebi, Antalya Phaselis Antik Kentinin korunması, belirli bir reklamda kadın cinsiyetinin aşağılanmasının engellenmesi, alttan alınan ders ücretlerinin kaldırılması gibi yerel konuları içermektedir. İmzaya açılan dilekçeler genelde Facebook ve Twitter üzerinden sosyal medyada duyurulmakta, kampanyanın daha verimli olmaya sağlanmasına çalışılmaktadır. Konunun önemine göre kampanyanın dijital veya geleneksel medyada yer aldığı örnekler de bulunmakta, hatta zaman zaman konular soru önergesi biçiminde Meclis'e de taşınabilmektedir (Facebook, Erişim Tarihi: 16.12.2017) (Twitter, Erişim Tarihi: 16.12.2017).Ancak en önemli tespit şudur ki; Change.org'un yegane çalışma şekli site üzerinden yapılan imza kampanyalarıdır. Sadece dijital ortam kullanılmaktadır.

\section{ARAŞTIRMA}

\subsection{Araştırmanın Amacı}

Çalışmaya konu olan aktivist platform; iletişim teknolojisini siyasal ve ekonomik süreçlerin temsilcisi sayan, teknoloji tarafından belirlenen 'bilgi tekelleri’nin, siyasal erkin toplumsal gruplar arasındaki bölüşümünü yönettiği (İrge, 2012: 67) ve toplumdaki mahrum grupların güç elde etmek için teknolojik gelişmelere önderlik ettiği görüşünü dile getiren Harold Innis'in (2006) çalışmaları bağlamında incelenmektedir. Çalışmanın amacı, dijital iletişim teknolojilerinin toplumsal örgütlenme biçimlerine etkilerini anlamamız kolaylaştırmak ve tüm bu başarıya ulaşmış projeler arasında anlamlı bir korelasyon olup olmadığını ortaya koymaktır.

\subsection{Araştırmanın Örneklemi}


Araştırmanın örneklemi, yargısal örneklem tekniği ile küresel boyutta en yaygın çalışma alanına sahip dijital aktivist organizasyonu olan Change.org kuruluşu ve bu kuruluşta belirli zaman aralığında başarıya ulaşmış 30 proje ile sınırlı tutulmuştur. Özellikle başarıya ulaşmış projelerin seçilmiş olması, kampanyanın başlangıcından, başarılı kabul edilerek tamamlanmasına dek geçen süreçler boyunca incelenmeye değer daha çok veri toplamış olmasındandır.

\subsection{Araştırmanın Önemi}

Çalışmanın önemi, dijital iletişim teknolojilerinin yaşam biçimlerimizi dönüştürmekte olduğu ve geleneksel medya yoluyla seslerini duyurmakta zorlanan alternatif görüşlerin bu teknolojiler sayesinde nasıl örgütlenebildiklerini göstermekle birlikte, hedefine ulaşmış projelerin ortak özelliklerinin veya farklılıklarının irdelenmesine dayanmaktadır.

\subsection{Yöntem}

Çalışmada betimleyici analiz yöntemi kullanılarak Change.org web sitesi derinlemesine incelenmiş, başarılı projeler analiz edilirken elde edilen sayısal veriler içerik çözümlemesi tekniği kullanılarak tablolaştırılmıştır. Change.org'un başarıya ulaşmış projelerinin listesine erişim tarihi, 02 Kasım 2015 -2 Aralık 2015'dir. Bu tarihler arasında web sitesi başarıya ulaşmış kampanyaların listesini yayınlamaktadır. Bu tarihler arasında Change.org sitesinin yayınlamış olduğu başarıya ulaşmış projeler listesinin ilk 30 projesi araştırma kapsamında değerlendirilmiştir. Belirlenen tarih aralıkları sadece sitenin yayınlamış olduğu "başarılı olmuş projelerin listesine" erişim tarihleridir. Projelerin o tarihler arasında başarıya ulaştığı anlamı çıkarılmamalıdır. Çalışmaya konu olan 30 proje; konusu, başarı süresi, imza adedi, kampanyayı başlatan, kampanyanın muhatabı, kampanyanın geleneksel ve sosyal medyada yer alıp almadığı, kampanya konusunun TBMM'de görüşülüp görüşülmediği başlıkları altında kategorize edilmiş, kodlamalar bu başlıklara göre yapılmıştır. Değerlendirme tüm bu başlıklar arasında bir korelasyon olup olmadığını içermekte ve bir başarı indeksi oluşturmayı hedeflemektedir.

\subsection{Bulgular}

Araştırma kapsamında Change.org sayfasında 2 Kasım-2 Aralık 2015 tarihleri arasında sıralanan başarıya ulaşmış 30 proje konu başlıklarına göre 7 kategoriye ayrılarak incelenmiştir. Bu konu başlıkları, proje sayısına göre sıralandığında 6 adet sağlık, 5 adet çevre, 4 adet hayvan hakları, 4 adet eğitim, 3 adet kadın hakları, 2 adet eğlence ve farklı konu başlıklarında 6 projenin yer aldığı diğer seçeneği şeklindedir.

Tablo 1: Sağılı Konulu Kampanyalar

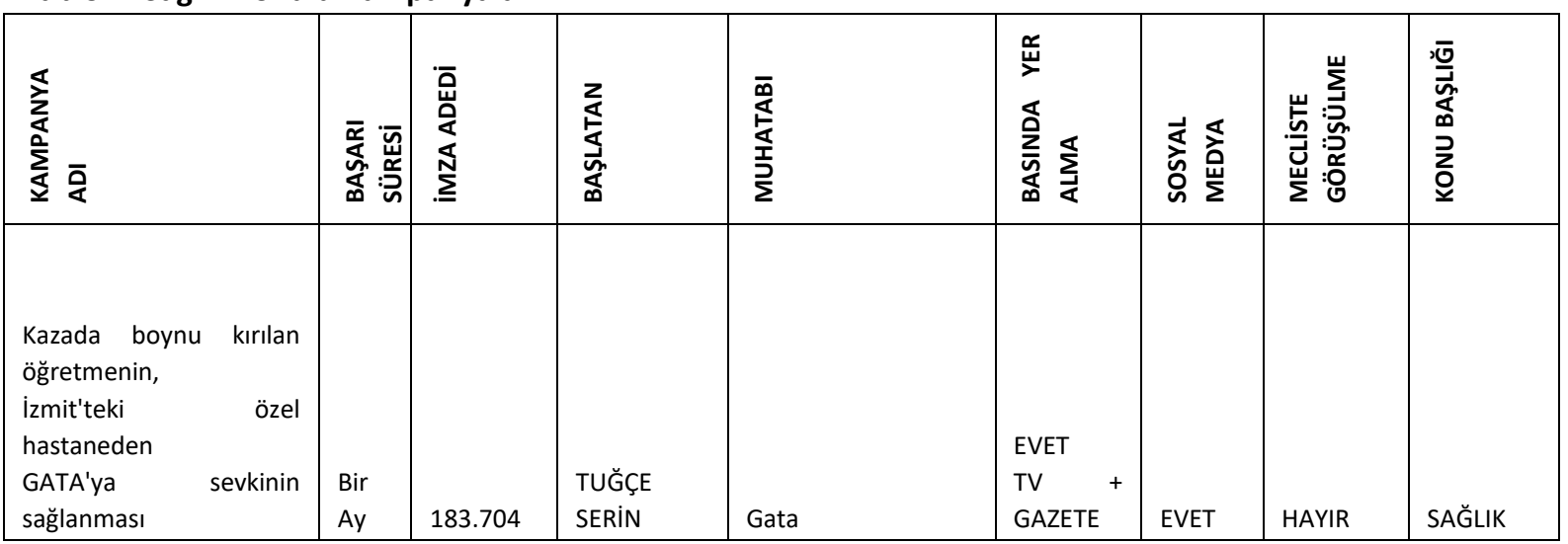




\begin{tabular}{|c|c|c|c|c|c|c|c|c|}
\hline $\begin{array}{l}\text { MPS 4A hastalı̆̆ının } \\
\text { tedavisi için gerekli olan } \\
\text { VIMIZM adlı ilacın SGK } \\
\text { kapsamına alınması }\end{array}$ & $\begin{array}{l}\text { Üç } \\
\text { Ay }\end{array}$ & 367.545 & $\begin{array}{l}\text { ŞAHIN } \\
\text { YILDIZ }\end{array}$ & $\begin{array}{l}\text { Sağlık Bakanı + } \\
\text { Çalışma Ve Sos.Güv. } \\
\text { Bakanı + Maliye } \\
\text { Bakanı +Başbakan }\end{array}$ & $\begin{array}{l}\text { EVET } \\
\text { TV } \\
\text { GAZETE }\end{array}+$ & EVET & EVET & SAĞLIK \\
\hline $\begin{array}{lr}\text { Bursa'da } & \text { engelli } \\
\text { kartlarına } & \\
\text { uygulanan } & \text { günlük } \text { biniş } \\
\text { kotasının } & \text { kaldırılması } \\
\text { talebi } & \\
\end{array}$ & $\begin{array}{l}\text { Bir } \\
\text { Ay }\end{array}$ & 203 & $\begin{array}{l}\text { MERT } \\
\text { CANBERK }\end{array}$ & $\begin{array}{l}\text { Bursa Büyükşehir } \\
\text { Belediyesi } \\
\text { Burulaş }+ \text { Aile Ve } \\
\text { Sosyal Politikalar } \\
\text { Bakanlığı }\end{array}$ & HAYIR & EVET & HAYIR & SAĞLIK \\
\hline $\begin{array}{l}\text { Duchenne } \text { M.D. hastası } \\
\text { çocukların tedavisi için } \\
\text { gerekli ilacın SGK } \\
\text { kapsamına alınması }\end{array}$ & $\begin{array}{l}\text { Üç } \\
\text { Ay }\end{array}$ & 3.069 & $\begin{array}{l}\text { CELAL } \\
\text { TÜNTAŞ }\end{array}$ & $\begin{array}{l}\text { Başbakanlık }+ \\
\text { Cumhurbaşkanı+ } \\
\text { Sosyal Güvenlik } \\
\text { Kurulu }\end{array}$ & HAYIR & EVET & HAYIR & SAĞLIK \\
\hline $\begin{array}{lr}\text { ILO'nun Madenlerde } \\
\text { Güvenlik ve } \\
\text { Sözleşmesinin } \\
\text { tarafından } \\
\text { imzalankiye } \\
\text { imzası isteniyor }\end{array}$ & $\begin{array}{l}\text { İki } \\
\text { Ay }\end{array}$ & 276.573 & HILAL ATICI & $\begin{array}{lrr}\text { Çalışma } & \text { Ve } & \text { Sosyal } \\
\text { Güvenlik } & \text { B.Lığı + } \\
\text { Enerji Ve } & \text { Tabii } \\
\text { kaynaklar } & \text { B.Lığı } \\
\text { +Meclis } & \text { Başkanın } \\
\text { Cemil Çiçek } & \end{array}$ & EVET & EVET & EVET & SAĞLIK \\
\hline $\begin{array}{l}\text { Daha önce var olup } \\
\text { sonradan kapatılan } \\
\text { ücretsiz ve anonim HIV } \\
\text { testi yaptırılabilecek } \\
\text { Gönüllü Danışmanlık ve } \\
\text { Test Merkezlerinin } \\
\text { tekrar açıması ve } \\
\text { bunların yurt çapında } \\
\text { yaygınlaştırılması }\end{array}$ & $\begin{array}{l}\text { Bir } \\
\text { YII }\end{array}$ & 5.390 & $\begin{array}{l}\text { POZITiF } \\
\text { YAŞAM } \\
\text { DERNEĞi }\end{array}$ & $\begin{array}{l}\text { Sosyal Medya-Sağlık } \\
\text { Bakanlığı } \\
\text { Sağlık Bakanlığı + } \\
\text { Aile Ve Sosyal } \\
\text { Politikalar B.Lığı }\end{array}$ & HAYIR & EVET & HAYIR & SAĞLIK \\
\hline
\end{tabular}

Tablo genel olarak incelendiğinde en çok sağlıkla ilgili projelerin başarıya ulaştığı görülmektedir. Sağlık konulu projelerin başarıya ulaşma sürelerine bakıldığında ise, altı projeden beşinin üç ay içerisinde başarıya ulaştığı, bir projenin ise başarıya ulaşması için kampanya başlangıcından itibaren bir yıl geçmiş olduğu görülmektedir. Daha uzun sürede başarıya ulaşan projenin birey yerine bir dernek tarafından başlatıldığı, diğer projelerin kişi bazında başlatıldığı izlenmektedir. Sağıı konularında başlatılan imza kampanyalarının muhatap olarak Sağlık Bakanlığı, Çalışma ve Sosyal Güvenlik Bakanlığı, Aile ve Sosyal Politikalar Bakanlığı, Başbakanlık, Cumhurbaşkanlığı gibi resmi devlet makamlarını aldıkları görülmektedir. Kampanyaların ikisinde belirli hastalıkların tedavisi için gerekli olan ilaçların SGK kapsamına alınması talep edilmektedir ve her iki kampanya da üç ay içinde sonuca ulaşmıştır. Kazada boynu kırılan bir öğretmenin tedavi olduğu hastaneden GATA'ya sevk edilmesini talep eden kampanya ise bir ayda başarılı olmuş, kampanya münferit bir konuyu ele almış olmasına rağmen 180.000 'in üzerinde destekçi kazanmıştır.

Projelerin imza adetlerine bakıldığında bunun başarı için tek belirleyen olmadığı görülmektedir. Yerel yönetimi muhatap alan bir proje 203 imza ile başarıya ulaşırken, Sağlık Bakanlığı, Çalışma ve Sosyal Güvenlik Bakanlığı, Maliye Bakanlığı ve Başbakanlığı muhatap alan bir diğer proje 367.545 imza ile başarıya ulaşmıştır. Tabloda imza sayısı diğerlerine oranla daha yüksek olan projelerin aynı zamanda hem geleneksel medyada (TV, gazete vb.) hem de sosyal medyada haber olarak yer aldığı görülmektedir. Sağlıkla ilgili başarıya ulaşmış projelerin tamamı sosyal medyada yer alırken, imza sayısı 10.000'in altında olanların geleneksel medyada yer almadığı izlenmektedir. İmza sayısı yüksek olan projelerin aynı zamanda TBMM'de de görüşmelere konu olduğu 
görülmektedir. Bunun nedeni hem imza sayısının fazlalığı hem de muhatap olarak çeşitli bakanlıkların seçilmiş olması şeklinde düşünülebilir.

Ayrıca, diğer konu başlıklarındaki projelerle karşılaştırıldıklarında sağlık konulu projelerin sayısal olarak çok daha fazla imza toplayabildikleri görülmektedir. Change.org gibi sosyal aktivizm sitelerinde imza sayıları baskı unsuru olma açısından önemli olmakla birlikte, projenin muhatabı ve tüm medya seçeneklerinde projenin duyurulması da başarıya ulaşmada etkili unsurlardır.

Tablo 2: Çevre Konulu Kampanyalar

\begin{tabular}{|c|c|c|c|c|c|c|c|c|}
\hline 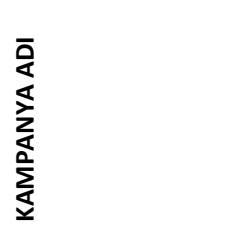 & 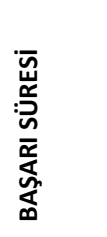 & 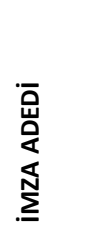 & 迹 & 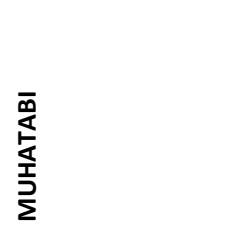 & 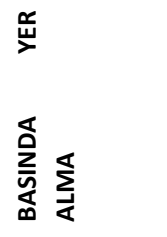 & 离 & 宸 & 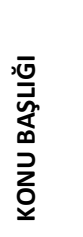 \\
\hline 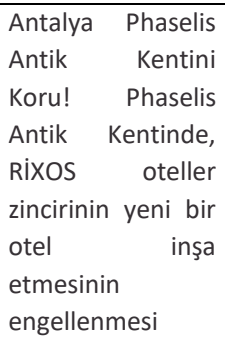 & 1,5 Y II & 95,305 & $\begin{array}{l}\text { MELIKE } \\
\text { VERGILI }\end{array}$ & $\begin{array}{l}\text { Kültür ve Turizm } \\
\text { Bakanı, } \\
\text { Orman ve Su İşleri } \\
\text { Bakanı } \\
\text { Çevre ve Şehircilik } \\
\text { Bakanı }\end{array}$ & $\begin{array}{l}\text { EVET } \\
\text { TV+GAZETE }\end{array}$ & EVET & HAYIR & ÇEVRE \\
\hline $\begin{array}{l}\text { Türkiye'nin } \\
\text { zeytinliklerinin } \\
\text { ölüm fermanına } \\
\text { hayır! TBMM'ye } \\
\text { getirilen zeytinlik } \\
\text { alanların vasfını } \\
\text { değiştirmeyi } \\
\text { öngören yasanın } \\
\text { çıkmasını } \\
\text { engellemek }\end{array}$ & Altı Ay & $\begin{array}{l}201,25 \\
9\end{array}$ & $\begin{array}{l}\text { SALIH } \\
\text { MADRA }\end{array}$ & $\begin{array}{ll}\text { TARIM VE KÖY } \\
\text { IŞLERI } \\
\text { KOMISYONU } \\
\text { Kişi }\end{array}$ & EVET GAZETE & EVET & EVET & ÇEVRE \\
\hline $\begin{array}{l}\text { Geyikbayırı } \\
\text { Tırmanış } \\
\text { Bölgesine } \\
\text { verilmiş olan } \\
\text { maden arama } \\
\text { Ruhsatının iptali } \\
\text { İsteniyor }\end{array}$ & Üç Ay & 17.822 & $\begin{array}{l}\text { ZÜLEYHA } \\
\text { GÖRKEN }\end{array}$ & $\begin{array}{lr}\text { Enerji Ve } & \text { Tabii } \\
\text { Kaynaklar } & \\
\text { Bakanlığı } & + \\
\text { Maden } & \text { Isşleri } \\
\text { Müdürlüğü } & \end{array}$ & EVET & EVET & HAYIR & ÇEVRE \\
\hline $\begin{array}{lr}\text { Burdur } & \text { Gölü } \\
\text { kuruyor } & \text { ve } 20 \\
\text { sene } & \text { içinde } \\
\text { tümüyle } & \text { yok } \\
\text { olma } & \text { tehlikesiyle } \\
\text { karşı } & \\
\text { karşıya. } & \\
\end{array}$ & $\begin{array}{l}\text { HEME } \\
\mathrm{N}\end{array}$ & 6.549 & $\begin{array}{l}\text { ÖZTÜRK } \\
\text { SARICA }\end{array}$ & $\begin{array}{ll}\text { Tüm } & \text { Dünya } \\
\text { İnsanları } & \end{array}$ & EVET & EVET & HAYIR & ÇEVRE \\
\hline $\begin{array}{l}\text { Kamilet Vadisinde } \\
\text { HES projelerinin } \\
\text { iptal }\end{array}$ & $\begin{array}{l}\text { İki Yıl, } \\
\text { Yedi } \\
\text { Ay }\end{array}$ & 34.298 & $\begin{array}{l}\text { HATICE } \\
\text { KESTANE }\end{array}$ & $\begin{array}{l}\text { Orman Ve Su işleri } \\
\text { Bakanlığı +Doğa } \\
\text { Koruma Ve Milli }\end{array}$ & $\begin{array}{l}\text { EVET } \\
\text { GAZETE + TV }\end{array}$ & EVET & EVET & ÇEVRE \\
\hline
\end{tabular}




\begin{tabular}{|l|l|l|l|l|l|l|}
\hline vadinin Tabiatı & & & Parklar Genel & & \\
Koruma Alanı ve & & & Müdürlüğü + & & \\
Milli Park & & & Enerji Ve Tabii & & \\
ilan edilmesi & & & Kaynaklar \\
talep ediliyor. & & & & \\
\hline
\end{tabular}

Change. org sosyal aktivizm sitesinde değerlendirmeye alınan 30 başarılı projede sayısal çoğunluk olarak ikinci sırada çevre konularında açılan projeler bulunmaktadır. Çevre konusunda açılan beş projenin değerlendirmesi şu şekildedir:

Projelerin başarı sürelerine bakıldığında herhangi bir genelleme yapmak oldukça zor görünmektedir. Hemen başarıya ulaşmış bir proje olmasına rağmen iki yıl, yedi ay gibi oldukça uzun sürede başarıya ulaşmış proje de yer almaktadır. Çevre konulu projelerin imza adetlerine baktığımızda ise, en çok imza ile başarıya ulaşmış projenin “Türkiye'nin zeytinliklerinin ölüm fermanına hayır!” kampanya adı ile TBMM'ye getirilen, zeytinlik alanların vasfını değiştirmeyi öngören yasanın çıkmasını engellemek üzere başlatılan bir proje olduğu görülmektedir. Projenin muhatabı olarak Tarım ve Köy İşleri Komisyonunda yer alan 40 kişi belirlenmiştir. Bu kadar spesifik bir proje muhatabı diğer projelerde görülmemekte, genellikle konuya ilişkin birkaç bakanlık muhatap olarak alınmaktadır. Projenin başarıya ulaşma süresi ise altı aydır. Proje aynı zamanda TBMM'de de görüşülmüştür. Çevre konulu projelerde ikinci en yüksek imzayı (94.305) toplayan ve bir buçuk yılda başarıya ulaşan, geleneksel ve sosyal medyaya da yansıyan, Kültür ve Turizm Bakanlığını, Orman ve Su İşleri Bakanlığını ve Çevre ve Şehircilik Bakanlı̆̆ını muhatap alan projenin konu başlığı ise "Antalya Phaselis Antik Kentini Koru"dur. Phaselis Antik Kentinde RiXOS oteller zincirinin yeni bir otel inşa etmesini engellemek üzere başlatılan bir projedir ve başarıya ulaşmıştır.

Çevre konulu projeler arasında yer alan "Burdur Gölü kuruyor ve 20 sene içinde tümüyle yok olma tehlikesiyle karşı karşıya" konulu proje 6.549 imza ile hemen başarıya ulaşmıştır. Projenin muhatabı ise tüm dünya insanları olarak belirlenmiştir. Proje geleneksel ve sosyal medyada da yer almıştır. Bu sonucun aksine, başarıya ulaşmış çevre konulu projeler arasında en uzun sürede başarıyı yakalamış olan proje, Kamilet vadisindeki HES projelerinin iptal edilerek vadinin tabiatı koruma alanı ve milli park ilan edilmesi talebinin yer aldığı projedir. Projenin muhatabı Orman ve Köy İşleri Bakanlığı, Doğa Koruma ve Milli Parklar Genel Müdürlüğü, Enerji ve Tabii Kaynaklar Bakanlığı olarak belirtilmiştir. Proje 43.238 imza ile başarıya ulaşmıştır. Proje geleneksel medya ve sosyal medyada yer almıştır. Ayrıca TBMM'de de görüşülmüştür. Çevre konulu projelerin tamamının sosyal medyada yayınlanmalarının yanı sıra geleneksel medyada da yayınlandığı görülmektedir. Bu sonuç, son yıllarda tüm dünyada hızlanarak yayılmakta olan çevre bilincinin medyaya yansıması olarak da değerlendirilebilir. Başarıya ulaşmış çevre konulu projelerin tamamı yine şahıslar tarafından başlatılmıştır.

Tablo 3: Hayvan Hakları Konulu Kampanyalar

\begin{tabular}{|c|c|c|c|c|c|c|c|c|}
\hline 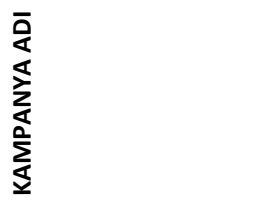 & 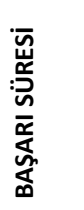 & 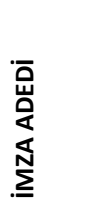 & 孞 & 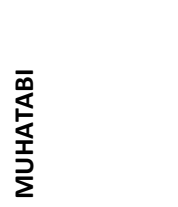 & 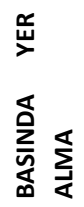 & 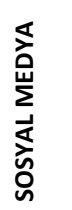 & 崖 & 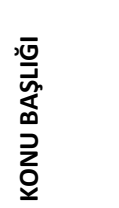 \\
\hline $\begin{array}{ll}\text { Sağlıksız } & \text { şartlarda } \\
\text { uygulama } & \\
\text { yapan } & \text { hayvan } \\
\text { barınağının } & \\
\text { iyileştirilmesi talebi }\end{array}$ & Üç Ay & 3.091 & $\begin{array}{l}\text { ÖZGÜR } \\
\text { ŞENIŞIK }\end{array}$ & $\begin{array}{l}\text { Bandırma } \\
\text { Belediyesi + } \\
\text { Balıkesir } \\
\text { Milletvekilleri }\end{array}$ & HAYIR & EVET & HAYIR & $\begin{array}{l}\text { HAYVAN } \\
\text { HAKLARI }\end{array}$ \\
\hline Hatem Yavuz adlı deri & Bir Ay & 65.363 & SIBEL & Hatem Yavuz & HAYIR & EVET & HAYIR & HAYVAN \\
\hline
\end{tabular}




\begin{tabular}{|c|c|c|c|c|c|c|c|c|}
\hline $\begin{array}{lr}\text { üreticisinin } & \text { fok } \\
\text { derisinden üretime } \\
\text { son vermesi } \quad \text { talep } \\
\text { ediliyor }\end{array}$ & & & TAMER & & & & & HAKLARI \\
\hline \begin{tabular}{l}
\multicolumn{2}{l}{ Migros'un } \\
raflardan kaldırdı̆̆ı \\
ürünleri imha \\
etmek yerine açlıkla \\
mücadele eden \\
hayvanlar yararına \\
kullanmasını \\
istiyoruz.
\end{tabular} & Bir Yıl & 23.816 & A.UFUK IŞIK & Migros & HAYIR & EVET & HAYIR & $\begin{array}{l}\text { HAYVAN } \\
\text { HAKLARI }\end{array}$ \\
\hline $\begin{array}{l}\text { Orman ve Su İşleri } \\
\text { Bakanlığı, } \\
\text { Valiliği: Hatay Dağ } \\
\text { Ceylanlarının yaşam } \\
\text { alanındar çimento } \\
\text { fabrikası istemiyoruz. }\end{array}$ & 1,5 Yıl & 610 & $\begin{array}{l}\text { TÜRKIYE } \\
\text { TABIATINI } \\
\text { KORUMA } \\
\text { DERNEĞi }\end{array}$ & $\begin{array}{l}\text { Orman Ve Su } \\
\text { işleri } \\
\text { Bakanlığı } \\
\text { İçişleri } \\
\text { Bakanlığı }\end{array}$ & EVET & EVET & HAYIR & $\begin{array}{l}\text { HAYVAN } \\
\text { HAKLARI }\end{array}$ \\
\hline
\end{tabular}

Çalışma kapsamında değerlendirilen 30 proje arasında hayvan hakları konulu 4 proje yer almaktadır. Projelerin başarıya ulaşma süreleri bir ay ile bir buçuk yıl arasında değişmektedir. Kampanyaların hiçbiri TBMM'de görüşülmemiştir.

İmza sayılarına bakıldığında en düşük imzayı toplayan kampanya, 610 imza ile Türkiye Tabiatını Koruma Derneği tarafından başlatılan ve Orman ve Su İşleri Bakanlığı ile İçişleri Bakanlığının muhatap alındığı projedir. Proje, Hatay dağ ceylanlarının yaşam alanlarının korunmasına yöneliktir ve bu alanda yapılması planlanan çimento fabrikasının inşaatının engellenmesini talep etmektedir. Kampanya konusu kendine gerek sosyal medyada gerekse geleneksel medyada yer bulmuş, sonuca ulaşması için bir buçuk yıl geçmesi gerekse ve fazla destekçi bulamasa da proje başarıya ulaşmıştır. Hayvan hakları konusunda en fazla imzayı toplayan kampanya ise Hatem Yavuz isimli bir şahıs işletmesini muhatap olarak almıştır. Hatem Yavuz adlı deri üreticisinin fok derisinden üretime son vermesini talep eden proje 65.363 imza toplamış ve bir ayda sonuca ulaşmıştır. Bu kampanya bir yönüyle incelenen diğer kampanyalardan farklılık göstermektedir. Kampanya sürecinde 40.000 imza toplanması hedeflenmiş ve sonuçta bu hedefe ulaşılmıştır. Ancak deri üreticisi, fok derisinden üretim yapmaya son vermemiş, kampanya sadece hedeflenen imza sayısına ulaştığı için başarılı sayılmıştır.

Türkiye'nin tanınmış süpermarket zincirlerinden Migros'u muhatap alan bir projede, kuruluştan raflardan kaldırdığı ekmek, makarna, et ürünleri gibi gıda malzemelerini imha etmek yerine, açlıkla mücadele eden hayvanlar yararına kullanması talep edilmektedir. 24.000'e yakın destekçi bulan proje bir yıl sonunda başarıya ulaşmış, kuruluş, Hayvan Hakları Federasyonu ile iş birliği içinde pilot bölgelerde bu uygulamanın başlatıldığını, uygulamayı, başarıya ulaşması halinde tüm ülkeye yaymayı planladıkları yönünde bir açıklamada bulunmuştur.

Tablo 4: Eğitim Konulu Kampanyalar

\begin{tabular}{|c|c|c|c|c|c|c|c|c|}
\hline 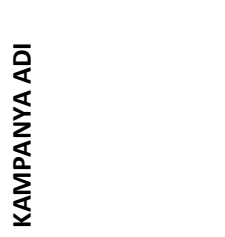 & 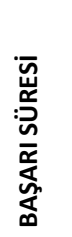 & $\begin{array}{l}\bar{u} \\
\text { à } \\
\text { s. } \\
. \underline{N}\end{array}$ & 孞 & 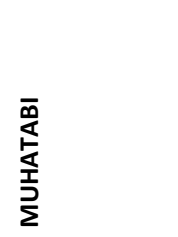 & 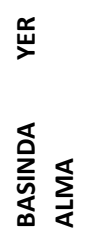 & 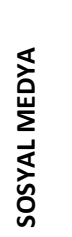 & 岁 & 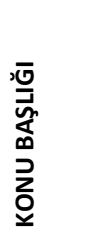 \\
\hline Her yıl katlamalı & Dört & 22.487 & KADIR AKBALIK & TBMM + Yök & EVET & EVET & EVET & EĞiTiM \\
\hline
\end{tabular}




\begin{tabular}{|c|c|c|c|c|c|c|c|c|}
\hline $\begin{array}{l}\text { şekilde } \\
\text { artan alttan alınan } \\
\text { ders } \\
\text { ücretlerinin } \\
\text { kaldırılması }\end{array}$ & Ay & & & $\begin{array}{l}+ \\
\text { Cumhurbaşka } \\
\text { nı }\end{array}$ & & & & \\
\hline $\begin{array}{l}\text { Her yıl katlamalı } \\
\text { şekilde } \\
\text { artan alttan alınan } \\
\text { ders } \\
\text { ücretlerinin } \\
\text { kaldırılması }\end{array}$ & $\begin{array}{l}\text { Dört } \\
\text { Ay }\end{array}$ & 32.841 & $\begin{array}{l}\text { OĞUZHAN } \\
\text { COŞKUN }\end{array}$ & YÖK & HAYIR & EVET & HAYIR & ЕĞітім \\
\hline $\begin{array}{l}\text { Esenyurtta oturan } \\
\text { Murat'a } \\
\text { Heybeliadada bir } \\
\text { okulda okuma } \\
\text { zorunluluğu } \\
\text { getirilmesi }\end{array}$ & Hemen & 6.092 & İDIL ÖZKARAKAYA & $\begin{array}{l}\text { Milli Eğitim } \\
\text { Bakanı Nabi } \\
\text { Avcı } \quad+ \\
\text { Aile Ve Sosyal } \\
\text { Politikalar } \\
\text { Bakanı } \\
\text { Ayşenur İslam }\end{array}$ & HAYIR & EVET & HAYIR & ЕĞітім \\
\hline $\begin{array}{lr} & \\
\text { İstanbul } & \text { Fatih } \\
\text { Kız Lisesi'nin } \\
\text { İmam Hatip } \\
\text { Lisesi r 'ne } \\
\text { dönüştürülmesi } \\
\text { ni istemiyoruz. }\end{array}$ & Bir Yıl & 867 & ŞAHIKA UÇER & $\begin{array}{l}\text { C.Başkanı } \\
\text { Abdullah Gül } \\
+ \\
\text { Milli Eğitim } \\
\text { Bakanı Nabi } \\
\text { Avcı } \\
\text { Başbakan } \\
\text { Erdoğan }\end{array}$ & EVET & EVET & HAYIR & ЕĞітім \\
\hline
\end{tabular}

Analiz edilen 30 başarıya ulaşmış proje arasında dört adet eğitim konulu proje yer almaktadır. Projelerin başarı süresi hemen ile bir yıl arasında değişmektedir. Hemen başarıya ulaşan proje, bir öğrencinin oturduğu bölgedeki bir okulda okuma isteğine yönelik bireysel bir örnektir, Milli Eğitim ile Aile ve Sosyal Politikalar Bakanlarını muhatap almıştır ve çok kısa sürede, 6092 imza ile başarıya ulaşmıştır. En fazla imza toplayan proje 32.841 imza ile YÖK'ü muhatap alan, her yıl katlamalı bir şekilde artan alttan alınan ders ücretlerinin kaldırımasına yönelik, çok sayıda öğrenciyi ilgilendiren bir projedir. Sadece bu proje TBMM'de görüşülmüştür. Aynı konuda, diğer bir kişi tarafından TBMM+YÖK+Cumhurbaşkanı muhatap alınarak benzer başlıkta ve aynı dönemlerde bir proje başlatılmış, bu kampanyada da 22.487 imzaya ulaşılmıştır.

Fatih'te yer alan Fatih Kız Lisesinin, İmam Hatip Lisesine dönüştürülmesini istemiyoruz konu başlıklı proje ise Cumhurbaşkanını, Başbakanı ve Milli Eğitim Bakanını muhatap almış, bir yılda 867 imza toplayarak başarıya ulaşmıştır. Gerek katlamalı biçimde artan ders ücretlerinin kaldırılmasına yönelik konu gerekse İstanbul Fatih Kız Lisesinin İmam Hatip Lisesine dönüştürülmemesi sosyal medyada olduğu kadar geleneksel medyada da kendine yer bulmuştur.

Tablo 5: Kadın ve İnsan Hakları Konulu Kampanyalar

\begin{tabular}{|c|c|c|c|c|c|c|c|c|}
\hline 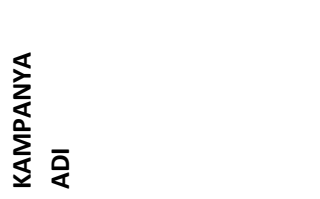 & 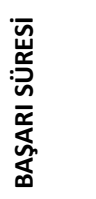 & $\begin{array}{l}\overline{\underline{u}} \\
\text { à } \\
\text { ș }\end{array}$ & 必 & 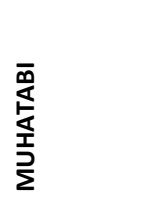 & 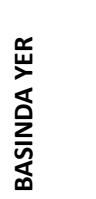 & 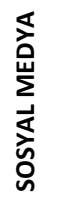 & 岕: & 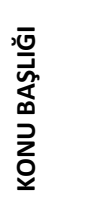 \\
\hline $\begin{array}{lr}\text { Doğadan } & \text { firmasının TV } \\
\text { Reklamını } & \text { cinsiyetçi } \\
\text { yaklaşımı } & \text { nedeniyle } \\
\text { yayından kaldırmak }\end{array}$ & İki Gün & 21.695 & MELIS ULUĞ & DOĞADAN & $\begin{array}{l}\text { EVET } \\
\text { GAZETE }\end{array}$ & EVET & HAYIR & $\begin{array}{l}\text { KADIN } \\
\text { HAKLARI }\end{array}$ \\
\hline Nihat Doğan'ın Survivor & Bir & 91.731 & NUR YILDIZ & ACUN ILICALI & EVET & EVET & HAYIR & KADIN \\
\hline
\end{tabular}




\begin{tabular}{|c|c|c|c|c|c|c|c|c|}
\hline $\begin{array}{l}\text { Yarışmasına } \\
\text { gönderilmemesinin } \\
\text { talep edilmesi }\end{array}$ & Hafta & & & $\begin{array}{l}+\quad \text { ACUN } \\
\text { MEDYA }\end{array}$ & & & & HAKLARI \\
\hline $\begin{array}{l}5 \text { kadından boşanan, iki } \\
\text { karısını bıçaklayarak } \\
\text { öldüren ve } 6 \text {. kadın ile } \\
\text { evlenmek isteyen adamın } \\
\text { cinayetlerinin programda } \\
\text { meşrulaştııılması ve Seda } \\
\text { Sayan'ın 'bu kadar güler } \\
\text { yüzlü bir katil olur mu' } \\
\text { demeci }\end{array}$ & Hemen & 3.167 & $\begin{array}{l}\text { FÜSUN } \\
\text { BUĞRA } \\
\text { KOLOĞLUGIL }\end{array}$ & RTÜK & EVET & EVET & HAYIR & $\begin{array}{l}\text { KADIN } \\
\text { HAKLARI }\end{array}$ \\
\hline $\begin{array}{lr}\text { Kobani IŞiD } & \text { tarafından } \\
\text { sarılı iken Irak Kürdistan } \\
\text { Bölgesel Yönetimi'nden ve } \\
\text { Rojava'daki r diğer } \\
\text { kantonlardan } & \text { Kobani'ye } \\
\text { gönderilecek insani, askeri } \\
\text { yardımların ulaştırılması } \\
\text { için, Türkiye'nin sınırları } \\
\text { içinde bir yardım koridoru } \\
\text { açması }\end{array}$ & Hemen & 48.110 & $\begin{array}{l}\text { CIZRE'DE } \\
\text { KATLIAMA } \\
\text { DUR DE } \\
\text { GiRişiMi }\end{array}$ & $\begin{array}{l}\text { TBMM } \\
\text { HÜKÜMET }\end{array}$ & HAYIR & EVET & HAYIR & $\begin{array}{l}\text { INSAN } \\
\text { HAKLARI }\end{array}$ \\
\hline
\end{tabular}

Incelenen 30 proje içinde üç adet Kadın Hakları ve bir adet İnsan Hakları konu başlığı olduğu görülmektedir. Bu kampanyaların en dikkat çekici yönü, başarıya ulaşma sürelerinin çok kısa oluşudur. Medyada kendine çok geniş yer bulan ve toplumun genelinin ilgisini çeken Özgecan Cinayeti sonrasında yapmış olduğu yorumlarla halkın tepkisini üzerine toplayan Nihat Doğan'ın, popüler bir yarışma programına katılmamasına yönelik olarak başlatılan ve muhatap olarak Acun Ilıcalı ve Acun Medya'yı seçen proje 91.731 ile kadın hakları konusunda en fazla imzayı toplamış projedir ve bir hafta içerisinde sonuçlanmıştır. Kadın hakları konulu üç projenin de televizyon programlarıyla ilgili olması ve kadınlara yönelik cinsiyetçi yaklaşımı ele alması dikkat çekicidir. Ayrıca üç proje de kadınlar tarafından başlatılmıştır. Kadın haklarını konu alan projelerin hiçbiri TBMM'de görüşülmemiştir, bunun nedeni olarak projelerin çok kısa sürede başarıya ulaşmış olması gösterilebilir.

Insan Hakları konu başlıklı kampanya Cizre'de Katliama Dur De Girişimi tarafından başlatılmış ve Türkiye Büyük Millet Meclisi ile Türk Hükümeti'ni muhatap almıştır. Girişimin başlattığı kampanyada Kobani İşid'e ait gruplarca sarılıyken oraya insani ve askeri yardımların ulaştırılabilmesi için Türk sınırları içinde bir yardım koridoru açılması talep edilmiş, kampanya 48.000 destekçiden imza toplamıştır.

Tablo 6: Farklı Konulu Kampanyalar

\begin{tabular}{|c|c|c|c|c|c|c|c|c|}
\hline 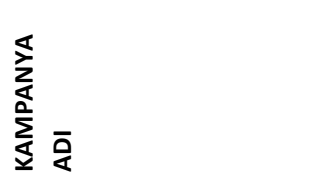 & 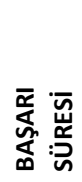 & $\begin{array}{l}\bar{D} \\
\text { 岁 } \\
\text { 衣 } \\
. \underline{\Sigma}\end{array}$ & 孞 & 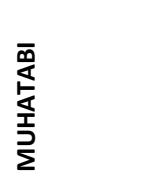 & 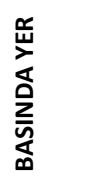 & 率 & 岕: & 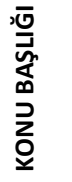 \\
\hline $\begin{array}{lr}\text { BJK'den } & \text { gönderilen } \\
\text { futbolcunun } & \text { geri } \\
\text { getirilmesi } & \end{array}$ & Bir Ay & 19.977 & Ozan Turhan & $\begin{array}{l}\text { F. Orman + } \\
\text { Quaresma } \\
+ \text { Bjk }\end{array}$ & $\begin{array}{l}\text { EVET } \\
\text { TV + } \\
\text { GAZETE }\end{array}$ & EVET & HAYIR & SPOR \\
\hline $\begin{array}{lr}\text { Fakülte } & \text { Tabelasından } \\
\text { kaldırılan } & \\
\text { T.C. ve } & \text { DTGSYO } \\
\text { ibarelerinin } & \end{array}$ & Bir Ay & 4.030 & $\begin{array}{l}\text { N.A. } \\
\text { (Kullanıcı } \\
\text { Profili } \\
\text { Kaldırılmış) }\end{array}$ & $\begin{array}{l}\text { Marmara } \\
\text { Üni. } \\
\text { Rektör+ } \\
\text { Güzel San. }\end{array}$ & HAYIR & EVET & HAYIR & KAMU \\
\hline
\end{tabular}




\begin{tabular}{|c|c|c|c|c|c|c|c|c|}
\hline tekrar yerine konması & & & & $\begin{array}{l}\text { Fak. } \\
\text { Dekanı }\end{array}$ & & & & \\
\hline $\begin{array}{l}\text { Günde } 15 \text { km yürüyen, } 20 \\
\text { yıllık TCDD çalışanı İbrahim } \\
\text { Çivici'ye } \quad \text { motivasyon } \\
\text { hediyesi } \\
\text { (Mümkünse } \\
\text { gönderilesiyle tatile }\end{array}$ & Bir Ay & 85.933 & $\begin{array}{l}\text { Rukiye } \\
\text { Demirkan }\end{array}$ & $\begin{array}{l}\text { Tcdd İk } \\
\text { Daire } \\
\text { Başkanlığı + } \\
\text { Turizm } \\
\text { Şirketleri } \\
\text { Ve Oteller }\end{array}$ & EVET & EVET & HAYIR & $\begin{array}{l}\text { SOSYAL } \\
\text { SORUMLU- } \\
\text { LUK }\end{array}$ \\
\hline $\begin{array}{l}\text { TBMM'deki parti grupla- } \\
\text { rından mevsimlik tarım } \\
\text { işçilerinin ve çocuklarının } \\
\text { sorunlarını çözecek bir } \\
\text { Meclis Araştırma } \\
\text { Komisyonu kurmaları }\end{array}$ & Üç Ay & 26.526 & $\begin{array}{l}\text { Hayata } \\
\text { Destek } \\
\text { Derneği }\end{array}$ & TBMM & EVET & EVET & EVET & işçi HAKLARI \\
\hline $\begin{array}{l}\text { "Bir beden büyük almayın. } \\
\text { Seneye de giymem. Moda } \\
\text { neyse onu giyerim." gibi } \\
\text { çocuklara olumsuz örnek } \\
\text { olması muhtemel Koton'un } \\
\text { billboardlarını kaldırması }\end{array}$ & Hemen & 37.468 & $\begin{array}{l}\text { N.A. } \\
\text { (Kampanya } \\
\text { Kazanıldıktan } \\
\text { sonra } \\
\text { Profil } \\
\text { Kaldırılmış) }\end{array}$ & Koton & EVET & EVET & HAYIR & ETIK \\
\hline $\begin{array}{l}\text { Yüksek görüntü kalitesine } \\
\text { sahip } \\
\text { sinemanın Ankara'daki } \\
\text { açıldığında iki filmi } \\
\text { gösterimden kalkmış da } \\
\text { olsa, göstermeleri talep } \\
\text { ediliyor }\end{array}$ & $\begin{array}{l}\text { Dört } \\
\text { Ay }\end{array}$ & 1.215 & BARIŞ ÜNVER & $\begin{array}{l}\text { Cınemaxım } \\
\text { um + Mars } \\
\text { Medıa }\end{array}$ & HAYIR & HAYIR & HAYIR & EĞLENCE \\
\hline $\begin{array}{l}\text { Giresun'a ilave dijital ve } \\
\text { yüksek görüntü kaliteli } \\
\text { sinema yapılması talebi }\end{array}$ & $\begin{array}{l}\text { Bir } \\
\text { Hafta }\end{array}$ & 328 & $\begin{array}{l}\text { www.giresun } \\
\text { blog.com }\end{array}$ & $\begin{array}{l}\text { Mars } \\
\text { Entertaınt } \\
\text { ment }\end{array}$ & HAYIR & EVET & Hayır & EĞLENCE \\
\hline
\end{tabular}

2 Kasım -2 Aralık 2015 tarihleri arasında Change.org sitesinde yayınlanan başarıya ulaşmış projelerin ilk 30'unda yer alan araştırma kapsamında değerlendirdiğimiz projelerin konu başlıklarına göre dağılımına baktığımızda, kimi konu başlıklarından 1-2 projenin yer aldığı görülmektedir. Bu projeler Tablo 6'da yer almaktadır. Tabloda görüldüğü üzere spor, sosyal sorumluluk, işçi hakları, etik vb. konu başlıklarında açılan projelerin en fazla dört ay gibi bir sürede başarıya ulaştıkları görülmektedir.

85.933 imza ile sosyal sorumluluk konulu bir kampanya en fazla imzayı toplayan projedir. Kampanya 'günde 15 km yürüyen, 20 yıllık TCDD çalışanı İbrahim Çivici'ye motivasyon hediyesi verilsin (mümkünse ailesiyle tatile gönderilsin)' başlığını taşımaktadır. Muhatap olarak TCDD İnsan Kaynakları Daire Başkanlığı ile turizm şirketleri ve otellerin belirlendiği proje bir ay içerisinde başarıya ulaşmıştır. Proje geleneksel ve sosyal medyada da kendine yer bulmuştur. Eğlence başlığı altında düzenlenen projeler ise sinema sektörüne yöneliktir ve her iki projenin de muhatabı Mars Entertainment'dır. İşletme açılan bu imza projelerini imza adetleri yüksek olmasa da karşılıksız bırakmamış ve kısa sürede olumlu adımlar atııştır.

“Bir beden büyük almayın. Seneye de giymem. Moda neyse onu giyerim, gibi çocuklara olumsuz örnek olması muhtemel propagandaları kınıyor, Koton'un billboardlarını kaldırmasını istiyoruz" konu başlıklı imza projesi hemen sonuç almış, firma ilanlarını billboardlardan kaldırmıştır. Projenin muhatabı KOTON firmasıdır ve proje 37.468 imza ile başarıya ulaşmıştır. Özellikle özel işletmelerin Change.org sitesi üzerinden başlatılan imza projelerine kısa süre içerisinde çözüm ürettikleri görülmektedir. Sosyal medyanın etkileşim özelliği dolayısıyla 
mesajların çok kısa sürede çok sayıda kişiye ulaştığı dikkate alındığında, günümüzde işletmelerin bu mecralardan verilen mesajlara kayıtsız ve duyarsız kalması durumunda başarılarının olumsuz yönde etkilenmesi güçlü bir olasılıktır.

İşçi Hakları konu başlıklı olan ve Hayata Destek Derneği tarafından açılan projenin konusu ise, TBMM'de bulunan tüm siyasi parti gruplarından mevsimlik tarım işçilerinin ve çocuklarının sorunlarını her yönüyle ele alıp çözecekleri bir Meclis Araştırma Komisyonu kurmalarını talep etmesidir. Proje 26.526 imza toplamış ve üç ayda sonuçlanmıştır. Proje geleneksel ve sosyal medyada yer almış, ayrıca TBMM'de görüşülmüştür. BJK takımından gönderilen futbolcunun geri getirilmesi isteğini belirten spor konulu kampanya ise 19,977 imza ile bir ayda başarıya ulaşmıştır.

Tablo 7: Proje Süresi, Proje Sayısı ve Proje Konusunun Karşılaştırılması

\begin{tabular}{|c|c|c|c|}
\hline SÜRE & PROJE SAYISI & \multicolumn{2}{|l|}{ PROJE KONUSU } \\
\hline $\begin{array}{l}\text { HEMEN } \\
\text { (BIR HAFTA) }\end{array}$ & 8 & $\begin{array}{l}\text { KADIN HAKLARI } \\
\text { EĞLENCE } \\
\text { EĞITIM } \\
\text { INSAN HAKLARI } \\
\text { ÇEVRE } \\
\text { ETIK }\end{array}$ & $\begin{array}{c}3 \\
1 \\
1 \\
1 \\
1 \\
1\end{array}$ \\
\hline BIR AY & 6 & $\begin{array}{l}\text { SAĞLIK } \\
\text { SPOR } \\
\text { KAMU } \\
\text { HAYVAN HAKLARI } \\
\text { SOSYAL SORUMLULUK }\end{array}$ & $\begin{array}{r}2 \\
1 \\
1 \\
1 \\
1\end{array}$ \\
\hline İKi - ÜÇ AY & 6 & $\begin{array}{l}\text { SAĞLIK } \\
\text { ÇEVRE } \\
\text { HAYVAN HAKLARI } \\
\text { işÇi HAKLARI }\end{array}$ & $\begin{array}{c}3 \\
1 \\
1 \\
1\end{array}$ \\
\hline DÖRT - ALTI AY & 4 & $\begin{array}{l}\text { ÇEVRE } \\
\text { EĞiTiM } \\
\text { EĞLENCE }\end{array}$ & $\begin{array}{l}1 \\
2 \\
1\end{array}$ \\
\hline BIR YIL VE ÜZERI & 6 & $\begin{array}{l}\text { ÇEVRE } \\
\text { SAĞLIK } \\
\text { HAYVAN HAKLARI } \\
\text { EĞiTIM }\end{array}$ & $\begin{array}{l}2 \\
1 \\
2 \\
1\end{array}$ \\
\hline & 30 & & 30 \\
\hline
\end{tabular}


30 başarıya ulaşmış proje başarı süreleri açısından incelendiğinde, bir hafta ile bir yıl ve üzeri arasında genel bir dağılım göstermekle birlikte, bir hafta içerisinde başarıya ulaşanların sayısının daha fazla olduğu görülmektedir. Bir hafta içerisinde başarıya ulaşan projelerin konuları ise genel bir dağılım göstermektedir. 30 projenin sekiz tanesi bir hafta içinde tamamlanmıştır. Kadın haklarına yönelik üç projenin de bir hafta içinde başarıya ulaşmış olması hayli dikkat çekicidir. Özellikle kadına yönelik şiddet haberlerinin günümüzde yoğun olarak medyada yer alıyor olması muhatap olarak belirlenen kurum ve kişilerin de bu konulara öncelik verdiğini göstermektedir. Sağlık konularında açılan projelerin ise çoğunlukla bir ile üç ay arasında başarı ile sonuçlandığı görülmektedir.

Tablo 8: Proje Konusu, Proje Sayısı ve İmza Sayısının Karşılaştırılması

\begin{tabular}{|c|c|c|c|}
\hline KONU BAŞLIĞI & PROJE SAYISI & $\begin{array}{l}\text { TOPLAM IMZA / } \\
\text { PROJE SAYISI }\end{array}$ & $\begin{array}{l}\text { PROJE BAŞINA } \\
\text { ORTALAMA IMZA ADEDI }\end{array}$ \\
\hline SAĞLIK & 6 & 836.484 / 6 & 139.414 \\
\hline SOSYAL SORUMLULUK & 1 & 85.933 / 1 & 85.933 \\
\hline ÇEVRE & 5 & $355.233 / 5$ & 71.047 \\
\hline INSAN HAKLARI & 1 & $48.110 / 1$ & 48.110 \\
\hline KADIN HAKLARI & 3 & $116.593 / 3$ & 38.864 \\
\hline ETIK & 1 & $37.468 / 1$ & 37.468 \\
\hline işÇi HAKLARI & 1 & $26.526 / 1$ & 26.526 \\
\hline HAYVAN HAKLARI & 4 & $92.880 / 4$ & 23.220 \\
\hline SPOR & 1 & 19.977 / 1 & 19.977 \\
\hline EĞiTiM & 4 & $62.287 / 4$ & 15.572 \\
\hline KAMU & 1 & 4.030 / 1 & 4.030 \\
\hline EĞLENCE & 2 & 1.543 / 2 & 771 \\
\hline & 30 & & \\
\hline
\end{tabular}

Başarıya ulaşmış 30 projenin proje konularına göre sayıları ile imza sayıları arasındaki bağlantılarına baktığımızda sağlık konulu projelerin sayıca daha fazla ve aynı şekilde topladıkları imza adetlerinin de diğer projelere göre daha yüksek olduğu görülmektedir. Analize tabi tutulan altı sağlık konulu kampanyada toplam 836.000 imza toplanmıştır ve her bir kampanyaya ortalama 140.000 civarında imza adedi düşmektedir. Bu durum, ülkemizde sağlık konusunun hala ciddiyetini koruduğu, çok sayıda bireyin sağlık hizmetleriyle ilgili sorunlar hakkında duyarlıığının bulunduğu biçiminde yorumlanabilir. Çevre konulu projelerin listedeki ağırlığı 
fazla olmasına rağmen imza ortalamalarına baktığımızda proje sayısıyla orantılı olarak yüksek olmadığı görülmektedir. Yine aynı şekilde eğitim ve hayvan haklarıyla ilgili projelerin imza sayısı ortalamalarının fazla yüksek olmadığını söylemek mümkündür.

\section{Tartışma ve Sonuç}

Teknolojik gelişmelerle bağlantılı olarak iletişim alanındaki değişimlerin yepyeni yaşam pratikleri oluşturduğu ve toplumsal hareketleri dönüştürdüğü yadsınamaz bir gerçektir. Konuyu Innis'in görüşleri bağlamında değerlendirdiğimizde (2006) medya, iktidar, bilgi üçlüsünün batılı ülkelerin yayılmacı politikalarına hizmet ettiği açıkça görülmekte, ancak bu kez yayılmacılık toprak işgali hüviyetinden kültürlerin dönüştürülmesine doğru bir değişim göstermektedir. Dijital medya çeşitlerinin çoğalması, internete erişimin ucuzlaması ve zaman/uzam farklarının yok olması sayesinde bilgi tekellerini ellerinde tutan güçler en ücra köşedeki kişilere ulaşmakta, onları istekleri doğrultusunda yönlendirmektedir.

Yayılmacı politikalara izin veren dijital teknolojilerin üreticileri ve dağıtımcıları bilgi tekellerini oluşturmakta, bu teknolojileri sattıkları ülkeleri kendilerine bağımlı hale getirmektedirler. Bilgi tekellerini ellerinde tutan egemen güçler ayrıca kendileri dışında araştırma, geliştirme yapan oluşumları denetleme, hatta gereği durumunda durdurma gücüne de sahiptirler. İletişim teknolojileri belki Innis'in savunduğu gibi toplumsal dönüşümlerin tek belirleyicisi değildir, ancak bu dönüşümde ciddi rol oynadığı bir gerçektir.

Geleneksel medya yoluyla seslerini duyuramayan alternatif görüşler, etkileşime izin veren internet sistemleri sayesinde bir araya gelebilmekte, gruplar oluşturabilmekte, hızlıca örgütlenerek aksiyon alabilmektedir. Change.org. gibi organizasyonların aktiviteleri de bu kapsamda değerlendirilmelidir. Oluşturulan kampanyaların bir diğer yararı da her gün uğradığımız enformasyon bombardımanı yüzünden gözden kaçan veya gündemden düşen önemli konuların gündemde kalmalarını sağlamaktır.

Change.org gibi aktivizm siteleri kişisel kullanıcıların sorun olarak algıladıkları konuları sosyal medya kullanıcılarının gündemine taşıma ve kendisine taraftar bulma konularında yardımcı platformlardır. Change.org aktivizm eylemi olarak sadece imza kampanyası düzenlenmesine olanak tanımaktadır. Çalışma kapsamında 2 Kasım - 2 Aralık 2015 tarihleri arasında Change.org internet ortamında listelenen, başarıya ulaşmış projelerin listesinden ilk 30 tanesi değerlendirilmiştir. Projelerin bu tarih aralığında başarıya ulaşmış olduğu anlaşılmamalıdır. Başarıya ulaşmış projelerin çeşitli konu başlıklarında değerlendirmesi yapılmıştır. Sağlık ve çevre konularında başarılı proje sayısı daha fazladır. Sağlık konularında açılan projelerin toplamış olduğu imza adedinin diğer projelere oranla daha yüksek olduğu görülmektedir. 30 projenin başlatıcılarına baktığımızda bireylerin açtığı projelerin, dernek ve vakıflara göre daha etkin olduğu izlenmektedir. Projelerin muhatapları ise genellikle kamu kuruluşları, TBMM ve bakanlıklar olarak görülmektedir. Özel kuruluşların ve yerel yönetimlerin kendilerini muhatap alan projelere daha kısa sürede olumlu dönüşler yaptığı da ayrıca izlenmektedir. 30 proje içerisinde kadın haklarına yönelik projelerin diğerlerine oranla daha kısa sürede başarıya ulaştığı görülmektedir. Başarıya ulaşmış 30 projenin tamamı sosyal medyada yer alırken 18'inin aynı zamanda geleneksel medyada da yer aldığının görülmesi, hem geleneksel medya hem de sosyal medyanın birbirlerini tamamladıkları, destekledikleri yorumuna yol açmakta, ayrıca dijital ortamda da olsa sayısal çoğunluk sağlanması, bir konunun geleneksel medyada haber olunması yönünde baskı sağladığı biçiminde değerlendirilebilmektedir.

Change.org gibi aktivist eylemlerin gerçekleştirildiği siteler, bireylerin yaşamış oldukları sorunlar karşısında ya da belli konularda göstermiş oldukları duyarlılıklara, alternatif çözümler üretme, seslerini hem yetkili organlara duyurma hem de kendileri gibi düşünen, hisseden insanların desteğini sağlama açısından önemli platformlardır. Gelişen, değişen ve hızla dönüşen yeni dünya düzeninde iletişim teknolojileri bundan önceki dönemlerde olduğu gibi etkinliğini fazlasıyla sürdürerek bir yandan insanların yeni sorunlarla karşı 
karşıya kalmalarını sağlarken bir yandan da yeni çözüm yolları sunarak bir anlamda kendilerini aklamaya çalışmaktadır. Özellikle yasama yetkisini elinde bulunduran siyasi otoritenin dikkatini belli konulara çekme ve istenilen doğrultuda kararlar çıkarılmasına vesile olması açısından Change.org gibi siteler önemli birer lobi aracı da olabilmektedir.

Henüz emekleme aşamasında olduğunu düşünülen yeni medya teknolojileri sayesinde gelecekte daha da farklı oluşumlarla karşılaşmamı beklenmelidir. Bu oluşumları anlamak ve değerlendirmek için bu alanda daha çok araştırmanın yapııması ise daha sonraki çalışmalara ışık tutacaktır.

\section{Kaynakça}

Arsava, F. ve Çerçi, V. (2006), “Avrupa Birliği'nde Lobicilik.” Ankara Üniversitesi Sosyal Bilimler Enstitüsü Uluslararası İlişkiler Anabilim Dalı, Bitirme Projesi.

Aslan, S. (2015), "Siyasal iktidarı Etkileme Yöntemlerinden Biri Olarak Lobicilik". Dumlupınar Üniversitesi, Sosyal Bilimler

Dergisi,23.

http://birimler.dpu.edu.tr/app/views/panel/ckfinder/userfiles/17/files/DERG /23/113-122.pdf.

$(18$ Aralık 2015)

Avar, B. (2015), “Nedir Bu Change.org?!” http://www.7-24haberci.com/yazarlar/banu-avar/nedir-bu-changeorg/828/. (16 Kasım 2015)

Aydoğan, D. (2013), “Türkiye' de Dijital Gazetecilik: Habertürk ve Hürriyet Gazeteleri Örneği”, The Turkish Online Journal of Design, Art and Communication - TOJDAC July 2013, 3-3, 26-40. (16.12.2017)

Geray, H. (2003), Illetişim ve Teknoloji: Uluslar arası Birikim Düzeninde Yeni Medya Politikaları, Ankara, Ütopya Yayınevi.

Grunig, J. vd. (2005), Halkla İlişkiler ve İletişim Yönetiminde Mükemmellik, İstanbul, Rota Yayınları.

Güngör, N. (2011), İletişim, Kuramlar ve Yaklaşımlar, Ankara, Siyasal Kitapevi.

Innis, H. A. (2006), İmparatorluk ve İletişim Araçları. Ankara, Ütopya Yayınevi.

İrge, N. F. (2012), "Enformasyon Toplumu ve Toplumsal Değişim Sürecinde Sosyal Medya." Akdeniz Iletişim 17, 63-86

Karpınar, A., (2016), http://www.aydinhedef.com.tr/yazi/atila-karpinar/06/06/2016/protesto. (16.12.2017)

Kınay, Ö. (2014), "Tüketim Olgusunun Sinemada Kullanımı: Fight Club Filminin incelenmesi", http://www.tojdac.org/tojdac/VOLUME4-ISSUE2 files/tojdac v04i207.pdf. (26 Aralık 2015)

Meriç, Ö. (2012), "Yeni Medya, Görsel Metinler ve Aktivizm." https://www.academia.edu/1511032/Yeni_Medya_G\%C3\%B6rsel Metinler ve Aktivizm. (27 Aralık 2015)

Paktin, S. (2013), “Change.org: Katılımcı Demokrasi ve Aktivizm”, http://ab.org.tr/ab13/bildiri/78.pdf. (06.12.2015)

Sert, N. Y. (2012), “Online Aktivizm Araçları Yoluyla Oluşturulan Etkilerin Metafor Kullanılarak Açıklanması, Örnek Olay İncelemesi: “internetime Dokunma” Eylemi” Akdeniz İletişim 17, 126-140.

Turhan, D. G. (2017), “Dijital Aktivizm”, Süleyman Demirel Üniversitesi Sosyal Bilimler Enstitüsü Dergisi, 26, 2644. http://sbedergi.sdu.edu.tr/assets/uploads/sites/343/files/26-yazi3-25042017.pdf (16.12.2017)

Türk, G. D. (2013), “Demokrasinin Dördüncü Kuvveti Yeni Medya Teknolojileri.” Inet-Tr'13, XVIII. Türkiye'de Internet Konferansı, İstanbul Üniversitesi. http://docplayer.biz.tr/2255237-Demokrasinin-dorduncukuvveti-yeni-medya-teknolojileri-gul-dilek-turk-marmara-universitesi-iletisim-fakultesi-istanbulguldilekturk-yahoo.html. (07 Aralık 2015)

Uçkan, Ö. (2012), “Dijital Aktivizm Mi, Aktivizm Mi?” https://spotdergi.wordpress.com. (06 Aralık 2015)

Vural, Z.B.A. (2010), "Yeni Bir İletişim Ortamı Olarak Sosyal Medya: Ege Üniversitesi İletişim Fakültesine Yönelik Bir Araştırma", Journal of Yaşar University, 20 (5), 3348-3382. 
http://www.tasam.org/Files/Icerik/File/yeni bir iletisim ortami olarak sosyal medya 45f56af6-aa864840-a8db-21f4bb4ab1dd.pdf (16.12.2017)

https://www.change.org/. (2.11. 2015, 9.12. 2015, 16.11.2017, Change.org)

https://www.facebook.com/Change.orgTurkey/?brand redir=83996318078. (16.12.2017, Facebook.com)

http://meydangazetesi.org/tag/change-org/ (21.01. 2017, Meydangazetesi.org)

http://www.tdk.gov.tr/index.php?option=com bts\&view=bts\&kategori1=veritbn\&kelimesec $=264140$

(16.12.2017, Tdk.gov.tr)

https://twitter.com/change. (16.12.2017, Twitter.com)

https://en.wikipedia.org/wiki/Change.org. (14.11.2015, Wikipedia.org) 